\title{
Halorubrum californiense sp. nov., an extreme archaeal halophile isolated from a crystallizer pond at a solar salt plant in California, USA
}

\author{
Peter T. Pesenti, ${ }^{1}$ Masoumeh Sikaroodi, ${ }^{1}$ Patrick M. Gillevet, ${ }^{1}$ \\ Cristina Sánchez-Porro, ${ }^{2}$ Antonio Ventosa ${ }^{2}$ and Carol D. Litchfield ${ }^{1}$
}

Correspondence

Antonio Ventosa

ventosa@us.es

\author{
${ }^{1}$ Department of Environmental Science and Policy, George Mason University, Manassas, VA 20110, \\ USA
${ }^{2}$ Department of Microbiology and Parasitology, Faculty of Pharmacy, University of Seville, 41012 Seville, Spain

\begin{abstract}
A motile, rod-shaped, pink-pigmented, extremely halophilic archaeon, strain SF3-213 ${ }^{\top}$, was isolated from a crystallizer pond at the Cargill Solar Salt Plant, Newark, California (USA). Analysis of the almost-complete 16S rRNA gene sequence showed that the isolate was phylogenetically related to species of the genus Halorubrum, with a close relationship to Halorubrum trapanicum NRC $34021^{\top}$ (98.6\% similarity), Halorubrum sodomense ATCC $33755^{\top}(98.3 \%)$ and Halorubrum xinjiangense AS $1.3527^{\top}$ (98.2\%). The polar lipids of strain SF3-213 ${ }^{\top}$ were $\mathrm{C}_{20} \mathrm{C}_{20}$ derivatives of phosphatidylglycerol, phosphatidylglycerol phosphate methyl ester, phosphatidylglycerol sulfate and a sulfated diglycosyl-diether. Strain SF3-213 ${ }^{\top}$ grew in 2.5$5.0 \mathrm{M} \mathrm{NaCl}$. The temperature and $\mathrm{pH}$ ranges for growth were $25-42{ }^{\circ} \mathrm{C}$ and $6.8-8.5$, respectively. Optimal growth occurred at 3.5-4.5 M NaCl, $37{ }^{\circ} \mathrm{C}$ and $\mathrm{pH}$ 7.3. $\mathrm{Mg}^{2+}$ was required for growth. The DNA G $+\mathrm{C}$ content was 69.4 mol\%. DNA-DNA hybridization values lower than $70 \%$ were obtained between strain SF3-213 ${ }^{\top}$ and the closely related species of the genus Halorubrum. Based on the data presented in this study, strain SF3-213 ${ }^{\top}$ represents a novel species for which the name Halorubrum californiense sp. nov. is proposed; the type strain is SF3 $-213^{\top}\left(=\right.$ CECT $7256^{\top}=$ DSM $19288^{\top}=$ JCM $\left.14715^{\top}\right)$.
\end{abstract}

Solar salterns harbour a diverse community of halophilic micro-organisms that represent the three domains of life: Archaea, Bacteria and Eukarya (Oren, 2002a). The archaeal members of the order Halobacteriales, family Halobacteriaceae, are significant components of higher salinity pans (Benlloch et al., 2002). The genus Halorubrum (McGenity \& Grant, 2001) is a member of the family and species of this genus are widely distributed in hypersaline environments, notably solar salterns (Kamekura 1998; Ochsenreiter et al., 2002; Oren, 2002a, b). The generic name Halorubrum was first proposed by Grant \& Ross (1986) for a distinct grouping of species within the genus Halobacterium. However, the genus Halorubrum was not officially recognized until the subsequent work of McGenity and Grant, which proposed the transfer of four species of Halobacterium to the new genus Halorubrum (McGenity \& Grant, 1995). The transfer was based on

Abbreviations: PG, phosphatidylglycerol; PGP-Me, phosphatidylglycerol phosphate methyl ester; PGS, phosphatidylglycerol sulfate; S-DGD, sulfated diglycosyl-diether.

The GenBank/EMBL/DDBJ accession number for the 16S rRNA gene sequence of strain SF3-213 ${ }^{\top}$ is EF139654. distinct phylogenetic clustering of the $16 \mathrm{~S}$ rRNA sequences of all four species, with Halorubrum saccharovorum as the type species (McGenity \& Grant, 1995). At the time of submission, 19 species were recognized within the genus Halorubrum: Hrr. saccharovorum (Tomlinson \& Hochstein, 1976), Hrr. lacusprofundi (Franzmann et al., 1988), Hrr. coriense (Kamekura \& Dyall-Smith, 1995; McGenity \& Grant, 1995), Hrr. distributum (Oren \& Ventosa, 1996), Hrr. sodomense (Oren, 1983; Oren \& Ventosa, 1996), Hrr. tebenquichense (Lizama et al., 2002), Hrr. terrestre (Ventosa et al., 2004), Hrr. trapanicum (McGenity \& Grant, 1995), Hrr. xinjiangense (Feng et al., 2004), Hrr. alkaliphilum (Feng et al., 2005), Hrr. tibetense (Fan et al., 2004), Hrr. vacuolatum (Kamekura et al., 1997; Mwatha \& Grant, 1993), Hrr. lipolyticum (Cui et al., 2006), Hrr. aidingense (Cui et al., 2006), Hrr. ezzemoulense (Kharroub et al., 2006), Hrr. orientale (Castillo et al., 2006), Hrr. arcis (Xu et al., 2007), Hrr. litoreum (Cui et al., 2007) and Hrr. ejinorense (Castillo et al., 2007). In this study, a novel strain that belongs to the genus Halorubrum is described and, based on phylogenetic, phenotypic and genotypic features and polar lipid composition, it is shown to represent a novel species. 
Strain SF3-213 ${ }^{\mathrm{T}}$ was isolated from water samples taken from a crystallizer pond at the Cargill Solar Salt Plant, Newark, California, USA $\left(37^{\circ} 29^{\prime} \mathrm{N} 122^{\circ} 1^{\prime} \mathrm{W}\right)$ in spring 1997. Samples were isolated on agar plates under aerobic conditions at $37{ }^{\circ} \mathrm{C}$ using a modified Casamino acid medium (MCAT) (Litchfield et al., 2005) containing the following ingredients $\left(1^{-1}\right)$ : Casamino acids, $7.3 \mathrm{~g}$; yeast extract, $0.51 \mathrm{~g}$; sodium citrate, $3 \mathrm{~g}$; solar salt, $250 \mathrm{~g}$; $\mathrm{MgSO}_{4} \cdot 7 \mathrm{H}_{2} \mathrm{O}, 20.0 \mathrm{~g}$; and $\mathrm{FeCl}_{3}, 0.02 \mathrm{~g}$. The $\mathrm{pH}$ was adjusted to 7.3 with $1 \mathrm{M} \mathrm{NaOH}$. The isolation methods have been described previously (Litchfield et al., 2005). Salt and temperature ranges were determined using a microtitre plate format with three replicates of each treatment read using a Packard SpectraCount microplate reader at $590 \mathrm{~nm}$. Salinity tolerance was tested at $0.5,1.5,2.0,2.5$, 3.0, 3.5, 4.0 and $5.0 \mathrm{M} \mathrm{NaCl}$. Separate plates with the above salt concentrations were incubated at $10,25,37$ and $42{ }^{\circ} \mathrm{C}$ and also read on the SpectraCount. The $\mathrm{pH}$ range was tested in buffered media at $\mathrm{pH} 5.0,6.0,6.5,6.8,7.0,7.3$, $7.8,8.0,8.5,9.0$ and 9.5. Strain SF3-213 ${ }^{\mathrm{T}}$ grew over the temperature range $25-42{ }^{\circ} \mathrm{C}$ (optimum $37^{\circ} \mathrm{C}$ ), with no growth at $20{ }^{\circ} \mathrm{C}$ or below, and at $\mathrm{pH} 6.8-8.5$ (optimum $\mathrm{pH}$ 7.3) when tested in buffered media. Routine cultivation was accomplished at $37^{\circ} \mathrm{C}$ and $\mathrm{pH}$ 7.3. Strain SF3-213 grew over a wide range of $\mathrm{NaCl}$ concentrations $(2.5-5.0 \mathrm{M})$ with optimal growth at $3.5-4.5 \mathrm{M} \mathrm{NaCl} . \mathrm{Mg}^{2+}$ was required for growth (optimum at $0.2 \mathrm{M}$ ) and growth was observed over the range $0.17-1.7 \mathrm{M}$.

A polyphasic taxonomic approach was followed for the phenotypic, chemotaxonomic and genotypic characterization of strain $\mathrm{SF} 3-213^{\mathrm{T}}$. All tests were performed in accordance with the proposed minimal standards for the description of new taxa in the order Halobacteriales (Oren et al., 1997). The type species Hrr. saccharovorum NCIMB $2081^{\mathrm{T}}$ was used as a reference; positive and negative controls were also used. Cell motility, morphology and Gram staining were examined using a Leica DM LB2 phase-contrast-equipped light microscope with an integrated Qimage camera (Retiga 1300) running BioQuant Nova Prime image analysis software v.6.90. Cells were taken from liquid media during early exponential growth. They were motile and rod-shaped by the hanging drop method and stained Gram-negative. Colony morphology was observed after growth at $37^{\circ} \mathrm{C}$ for 7 days on MCAT agar with $4.5 \mathrm{M}$ solar salt. Colonies of strain SF3-213 ${ }^{\mathrm{T}}$ were circular, $1.0-1.5 \mathrm{~mm}$ in diameter and slightly raised with light pink pigmentation. Anaerobic growth was tested with L-arginine in screw-topped sealed vials. Phenotypic characteristics were tested as described by Oren et al. (1997) and included the following tests: hydrolysis of starch, gelatin, casein, chitin, cellulose and Tween 80; nitrate reduction; production of $\mathrm{H}_{2} \mathrm{~S}$, indole, catalase and Kovac's oxidase; and the utilization of sugars and amino acids as carbon and energy sources. In parallel, API $20 \mathrm{NE}$ test strips (bioMérieux) were used for confirmation with a slight modification to the inoculum concentration to reduce high salt interference.
Strain SF3-213 ${ }^{\mathrm{T}}$ was positive for catalase and Kovac's oxidase. Indole was produced from tryptophan. Nitrate was reduced to nitrite. $\mathrm{H}_{2} \mathrm{~S}$ was not produced. Casein was hydrolysed, but starch, gelatin, chitin, cellulose and Tween 80 were not. In addition, the API 20 strips gave positive tests for aesculin and 4-nitrophenyl- $\beta$-D-galactopyranoside hydrolysis. The assimilation of sugars as single carbon sources was tested with modified Bushnell-Haas medium (Brown \& Braddock, 1990) supplemented with $0.05 \%$ (w/v) yeast extract, $2 \%(\mathrm{w} / \mathrm{v}) \mathrm{MgCl}_{2}, 0.01 \%(\mathrm{w} / \mathrm{v})$ sugar (D-glucose, D-fructose, lactose, D-galactose or mannose) and $25 \% \mathrm{NaCl}$. Strain $\mathrm{SF} 3-213^{\mathrm{T}}$ was positive for the assimilation of D-glucose, lactose and D-galactose and negative for $\mathrm{D}$-fructose and mannose. No acid was detected via $\mathrm{pH}$ meter readings for any of the sugars. Methyl red and Voges-Proskauer tests were negative. Utilization of various substrates and tests are summarized in the species description and Table 1.

Antibiotic susceptibilities were determined by the KirbyBauer (Bauer et al., 1966) method on large MCAT agar plates $(3.5 \mathrm{M} \mathrm{NaCl})$ with antibiotic discs containing the following concentrations: ampicillin $(10 \mu \mathrm{g})$, bacitracin (10 U), chloramphenicol $(5 \mu \mathrm{g})$, erythromycin $(15 \mu \mathrm{g})$, kanamycin $(30 \mu \mathrm{g})$, nalidixic acid $(30 \mu \mathrm{g})$, rifampicin $(5 \mu \mathrm{g})$ and streptomycin $(10 \mu \mathrm{g})$. The results are included in the species description.

Polar lipids were extracted using a chloroform/methanol system as described previously (Litchfield \& Oren, 2001). One-dimensional TLC was performed on 19-channel silica gel-G plates (Whatman) in a solvent system of chloroform/ methanol/acetic acid/water $(85: 22.5: 10: 4$, by vol.) in lined tanks. For two-dimensional TLC, single sheet silica gel-G plates were employed with chloroform/methanol/ acetic acid/water $(80: 12: 15: 4$, by vol.) as the solvent system in the first dimension and chloroform/methanol/ water $(65: 25: 4$, by vol.) in the second dimension (Litchfield \& Oren, 2001). Polar lipid fractions were detected with spray reagents: orcinol for glycolipids followed by heating to $110^{\circ} \mathrm{C}$; ammonium molybdate for phospholipids (Tindall, 1990); and cresyl violet for sulfolipids (Soto et al., 2000). The polar lipids of strain SF3-213 $3^{\mathrm{T}}$ are $\mathrm{C}_{20} \mathrm{C}_{20}$ derivatives of phosphatidylglycerol (PG), phosphatidylglycerol phosphate methyl ester (PGP$\mathrm{Me}$ ) and phosphatidylglycerol sulfate (PGS). In addition, a single sulfated diglycosyl-diether (S-DGD) was also detected. This polar lipid profile is typical of neutrophilic species of the genus Halorubrum (McGenity \& Grant, 2001).

Methods employed for genomic DNA extraction/preparation, PCR amplification of the 16S rRNA gene sequence and gene sequencing have been described previously (Litchfield et al., 2005). The haloarchaeal primers used for the PCR were HK 1F (ATTCCGGTTGATCCTGCCGG) and H1492R (GTTACCTTGCCCGTTCCTTC) (Litchfield et al., 2005). The almost complete $16 \mathrm{~S}$ rRNA gene sequence (1436 bp) of strain SF3-213 ${ }^{\mathrm{T}}$ was determined and com- 
Table 1. Distinguishing characteristics of strain SF3-213 ${ }^{\top}$ and other species of the genus Halorubrum

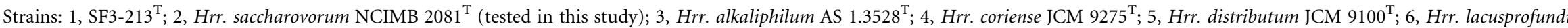

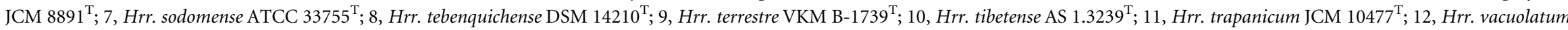
JCM $9060^{\mathrm{T}} ; 13$, Hrr. xinjiangense AS $1.3527^{\mathrm{T}} ; 14$, Hrr. ezzemoulense CECT $7099^{\mathrm{T}} ; 15$, Hrr. lipolyticum ICM 13559 ${ }^{\mathrm{T}} ; 16$, Hrr. aidingense JCM 13560 $; 17$, Hrr. orientale CECT $7145^{\mathrm{T}} ; 18$, Hrr. arcis AJ201 ${ }^{\mathrm{T}} ; 19$, Hrr. litoreum CGMCC $1.5336^{\mathrm{T}} ; 20$, Hrr. ejinorense CECT $7194^{\mathrm{T}}$. Data for strains 3-20 are from Feng et al. (2004, 2005), Ventosa et al. (2004), Lizama et al. (2002), McGenity \& Grant (1995), Cui et al. (2006, 2007), Castillo et al. (2006, 2007) and Xu et al. (2007). +, Positive; -, negative; +/-, doubtful; ND, no data available.

\begin{tabular}{|c|c|c|c|c|c|c|c|c|c|c|c|c|c|c|c|c|c|c|c|c|}
\hline $\begin{array}{l}\text { Characteris- } \\
\text { tic }\end{array}$ & 1 & 2 & 3 & 4 & 5 & 6 & 7 & 8 & 9 & 10 & 11 & 12 & 13 & 14 & 15 & 16 & 17 & 18 & 19 & 20 \\
\hline Morphology & Rods & Rods & $\begin{array}{r}\text { Short } \\
\text { rods }\end{array}$ & $\begin{array}{l}\text { Pleomor- } \\
\text { phic short } \\
\text { rods and } \\
\text { cup shapes }\end{array}$ & $\begin{array}{l}\text { Pleomor- } \\
\text { phic rods }\end{array}$ & $\begin{array}{l}\text { Pleomor- } \\
\text { phic rods }\end{array}$ & Rods & $\begin{array}{l}\text { Irregu- } \\
\text { lar } \\
\text { discs }\end{array}$ & $\begin{array}{l}\text { Pleomor- } \\
\text { phic }\end{array}$ & Rods & $\begin{array}{l}\text { Pleomor- } \\
\text { phic rods }\end{array}$ & $\begin{array}{l}\text { Pleomor- } \\
\text { phic short } \\
\text { rods }\end{array}$ & $\begin{array}{r}\text { Short } \\
\text { rods }\end{array}$ & $\begin{array}{l}\text { Pleomor- } \\
\text { phic }\end{array}$ & Rods & Rods & $\begin{array}{c}\text { Pleomor- } \\
\text { phic } \\
\text { rods }\end{array}$ & - Rods & Rods & Rods \\
\hline Cell size $(\mu \mathrm{m})$ & $\begin{array}{c}0.5 \times \\
1.0- \\
1.5\end{array}$ & $\begin{array}{c}0.6- \\
1.2 \times \\
2.5\end{array}$ & $\begin{array}{c}0.8-1.0 \\
\times 1.8- \\
2.0\end{array}$ & $5.0-0.5$ & $\begin{array}{l}0.8-1.0 \\
\times 2.7-7\end{array}$ & $>12$ & $\begin{array}{c}0.5 \times \\
2.5- \\
5.0\end{array}$ & $\begin{array}{l}0.8- \\
1.2 \times \\
1.5-1.0\end{array}$ & $\begin{array}{r}1.0-1.5 \times \\
1.5-2.5\end{array}$ & $\begin{array}{c}0.5-1.0 \\
\times 1.5- \\
2.5\end{array}$ & $\begin{array}{r}0.7-1.0 \times \\
1.5-3.0\end{array}$ & $\begin{array}{c}0.7-10.0 \times \\
1.5-3.0\end{array}$ & $\begin{array}{l}0.8- \\
1.2 \times \\
1.8-2.6\end{array}$ & $\begin{array}{l}0.6 \times \\
1.5-3.0\end{array}$ & $\begin{array}{c}0.9- \\
1.2 \times \\
1.8- \\
5.5\end{array}$ & $\begin{array}{c}0.9-1.0 \\
\times 3.6- \\
6.4\end{array}$ & $\begin{array}{c}1.5- \\
-\quad 2.0 \times \\
1.0-2.0\end{array}$ & $\begin{array}{c}0.5-1.0 \\
\times 2.0- \\
4.0\end{array}$ & $\begin{array}{c}0.3-0.51 \\
\times 2.0- \\
5.0\end{array}$ & $\begin{array}{c}1.0-1.5 \\
\times 5.0- \\
8.0\end{array}$ \\
\hline Motility & + & + & + & + & + & + & + & $\mathrm{ND}$ & + & - & - & - & + & + & + & + & + & + & + & - \\
\hline $\begin{array}{l}\mathrm{NaCl} \text { range } \\
\text { for growth } \\
\text { (M) }\end{array}$ & $2.5-5.0$ & $1.5-5.2$ & $1.8-5.2$ & $2.0-5.2$ & $1.7-5.2$ & $1.5-5.2$ & $0.5-4.3$ & $2.5-5.2$ & $2.5-5.2$ & $1.7-5.2$ & $2.5-5.2$ & $2.5-5.2$ & $2.0-5.2$ & $2.5-4.3$ & $1.7-4.8$ & $1.7-4.3$ & $32.5-5.0$ & $2.2-5.2$ & $2.0-5.12$ & $2.5-5.0$ \\
\hline pH optimum & 7.3 & $7.0-7.5$ & $9-10$ & $7.0-7.5$ & 7.5 & $7.0-7.5$ & $7.0-7.5$ & $\mathrm{ND}$ & 7.5 & $9.0-9.5$ & $7.0-7.5$ & 9.5 & $7.0-7.5$ & $7.0-7.5$ & 7.5 & 7.5 & 8.0 & 7.54 & $7.0-7.5$ & 7.5 \\
\hline $\begin{array}{l}\text { Nitrate } \\
\text { reduction }\end{array}$ & + & - & + & $\mathrm{ND}$ & + & $+1-$ & $+1-$ & + & - & + & + & + & - & + & + & + & + & + & + & + \\
\hline $\begin{array}{l}\text { Indole pro- } \\
\text { duction }\end{array}$ & + & - & - & - & - & - & - & - & - & - & - & - & - & - & - & + & - & $\mathrm{ND}$ & ND & - \\
\hline $\begin{array}{l}\text { Casein } \\
\text { hydrolysis }\end{array}$ & + & - & - & $\mathrm{ND}$ & - & - & $\mathrm{ND}$ & $\mathrm{ND}$ & - & $\mathrm{ND}$ & $\mathrm{ND}$ & $\mathrm{ND}$ & $\mathrm{ND}$ & ND & - & - & - & - & - & - \\
\hline $\begin{array}{l}\mathrm{Mg}^{2+} \\
\text { requirement } \\
\text { Utilization of: }\end{array}$ & + & + & - & + & $\mathrm{ND}$ & + & + & - & $\mathrm{ND}$ & - & $\mathrm{ND}$ & - & - & + & - & + & - & - & + & $\mathrm{ND}$ \\
\hline D-Glucose & + & + & + & + & - & + & + & + & - & + & + & + & + & + & + & + & + & + & + & - \\
\hline D-Galactose & + & + & - & + & - & + & - & + & ND & - & + & + & - & - & + & + & - & - & + & - \\
\hline Lactose & + & + & - & + & $\mathrm{ND}$ & + & + & - & $\mathrm{ND}$ & - & - & ND & - & $\mathrm{ND}$ & $\mathrm{ND}$ & $\mathrm{ND}$ & - & - & + & - \\
\hline D-Fructose & - & + & + & $\mathrm{ND}$ & $\mathrm{ND}$ & - & + & + & - & ND & + & - & + & - & + & + & + & - & - & - \\
\hline Mannose & - & + & + & + & + & + & $\mathrm{ND}$ & + & - & + & + & $\mathrm{ND}$ & - & - & + & + & $\mathrm{ND}$ & - & - & $\mathrm{ND}$ \\
\hline PGS present & + & + & - & + & + & + & + & - & + & - & + & - & + & + & + & + & - & + & + & - \\
\hline $\begin{array}{l}\text { DNA G +C } \\
\text { content } \\
(\text { mol\%) }\end{array}$ & 69.4 & 71.2 & 62.1 & ND & 63.6 & 65.3 & 67.4 & 63.2 & 64.4 & 63.3 & 64.3 & 62.7 & 68.7 & 61.9 & 65.9 & 64.2 & 64.2 & 65.7 & 64.9 & 64 \\
\hline
\end{tabular}


pared via BLAST to those of other members of the family Halobacteriaceae. The ARB software package (Ludwig et al., 2004) was used for 16S rRNA gene sequence analysis. Several treeing methods (maximum-likelihood, distance matrix and maximum-parsimony) were performed on the basis of the recommendations of Ludwig et al. (1998). Strain SF3-213 ${ }^{\mathrm{T}}$ showed the highest level of similarity with species of the genus Halorubrum, with the closest relationships to Hrr. trapanicum NRC $34021^{\mathrm{T}}$ (98.6\% similarity), Hrr. sodomense ATCC $33755^{\mathrm{T}}(98.3 \%)$ and Hrr. xinjiangense AS $1.3527^{\mathrm{T}}$ (98.2\%). The phylogenetic tree obtained by using the maximum-parsimony method shows strain SF3-213 ${ }^{\mathrm{T}}$ within the species of the genus Halorubrum (Fig. 1). These results were consistent with those obtained using other algorithms to construct phylogenetic trees. In addition, the $16 \mathrm{~S}$ rRNA gene sequence of strain SF3-213 matched the signature sequences for the genus Halorubrum at positions 199-229, 656-672 and 1242-1259 (positions based on the sequence of Escherichia coli) (Grant et al., 2001).

Chromosomal DNA of strain SF3-213 ${ }^{\mathrm{T}}$ was isolated and purified according to the method described by Marmur (1961). The G+C content of the genomic DNA was determined from the mid-point value $\left(T_{\mathrm{m}}\right)$ of the thermal denaturation profile (Marmur \& Doty, 1962) by using the equation of Owen \& Hill (1979) as described previously in detail by Ventosa et al. (1999). The DNA G + C content of strain $\mathrm{SF} 3-213^{\mathrm{T}}$ was $69.4 \mathrm{~mol} \%$, a relatively high value when compared with the close relatives mentioned above
(Table 1). DNA-DNA hybridization studies were performed according to the competition procedure of the membrane method (Johnson, 1994) as described in detail by Mormile et al. (1999). Strain SF3-213 ${ }^{\mathrm{T}}$ showed low DNA-DNA hybridization values to the closely related type strains of Hrr. distributum JCM $10118^{\mathrm{T}}$ (44\%), Hrr. trapanicum JCM $10477^{\mathrm{T}}$ (37\%), Hrr. terrestre VKM B- $1739^{\mathrm{T}}$ (33\%), Hrr. tebenquichense JCM $12290^{\mathrm{T}}$ (24\%), Hrr. saccharovorum ATCC $29252^{\mathrm{T}}(21 \%)$, Hrr. sodomense JCM $8880^{\mathrm{T}}(18 \%)$ and Hrr. xinjiangense JCM $12388^{\mathrm{T}}$ $(4 \%)$. These data show that strain SF3-213 ${ }^{\mathrm{T}}$ represents a different species, since the threshold value to separate two species is $70 \%$ (Stackebrandt \& Goebel, 1994).

The above phenotypic, genotypic, chemotaxonomic and phylogenetic data indicate that strain SF3 $-213^{\mathrm{T}}$ represents a novel species within the genus Halorubrum for which the name Halorubrum californiense sp. nov. is proposed. Differential characteristics of strain $\mathrm{SF} 3-213^{\mathrm{T}}$ and other species of the genus Halorubrum are shown in Table 1.

\section{Description of Halorubrum californiense sp. nov.}

Halorubrum californiense (ca.li.for.ni.en'se. N.L. neut. adj. californiense pertaining to California, USA, where the strain was isolated from a solar saltern).

Cells are Gram-negative and short-rod-shaped $(0.5 \times 1.0$ $1.5 \mu \mathrm{m})$. Motile. Colonies are small, round, $1.0-1.5 \mathrm{~mm}$ in diameter, pink, smooth and slightly raised. Extreme halophile. Growth occurs optimally at $3.5-4.5 \mathrm{M} \mathrm{NaCl}$

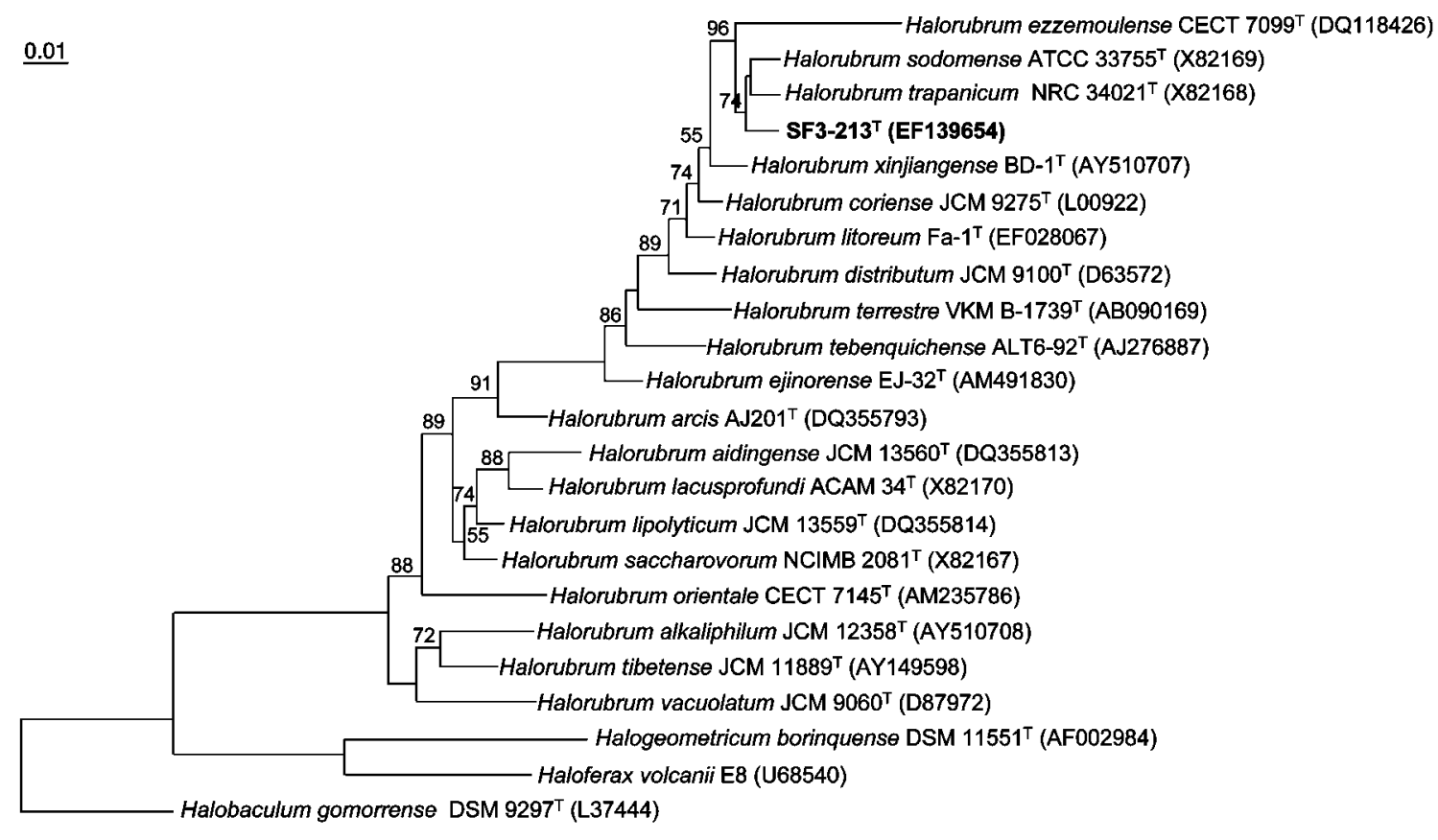

Fig. 1. Maximum-parsimony phylogenetic tree based on $16 \mathrm{~S}$ rRNA gene sequences showing the position of strain SF3-213 ${ }^{\top}$ among related species. Bootstrap values (\%) at the branches are based on 1000 replicates. The sequence data used were obtained from GenBank (accession numbers are given in parentheses). Bar, $1 \%$ sequence divergence. 
and over the range $2.5-5.0 \mathrm{M} \mathrm{NaCl}$. The $\mathrm{pH}$ range for growth is $6.8-8.5$, with optimum growth at $\mathrm{pH}$ 7.3. The temperature range is $25-42{ }^{\circ} \mathrm{C}$; optimal temperature for growth is $37{ }^{\circ} \mathrm{C}$. Magnesium is required for growth, with an optimum of $0.2 \mathrm{M}$ and growth over the range 0.17 1.7 M. Chemo-organoheterotrophic and strictly aerobic. Positive for catalase and Kovac's oxidase. Casein and aesculin are hydrolysed, but gelatin, starch, cellulose, chitin and Tween 80 are not. $\mathrm{H}_{2} \mathrm{~S}$ is not produced. Nitrate is reduced to nitrite. Indole is produced. Methyl red and Voges-Proskauer tests are negative. D-Glucose, lactose and D-galactose are used as single carbon sources. Mannose, Dfructose and acetate are not utilized. No acid production from sugars. Sensitive to bacitracin, kanamycin and nalidixic acid. Resistant to ampicillin, chloramphenicol, erythromycin, rifampicin and streptomycin. The polar lipids are $\mathrm{C}_{20} \mathrm{C}_{20}$ diether derivatives of PG, PGP-Me and PGS and a single glycolipid, S-DGD.

The type strain, SF3-213 ${ }^{\mathrm{T}} \quad\left(=\mathrm{CECT} \quad 7256^{\mathrm{T}}=\mathrm{DSM}\right.$ $19288^{\mathrm{T}}=\mathrm{JCM} 14715^{\mathrm{T}}$ ), was isolated from the crystallizer pond at the Cargill Solar Salt Plant in Newark, California, USA. The DNA $\mathrm{G}+\mathrm{C}$ content of the type strain is $69.4 \mathrm{~mol} \%\left(T_{\mathrm{m}}\right)$.

\section{Acknowledgements}

The authors appreciate the collection and isolation of numerous cultures from the saltern by Amy Irby. The authors also thank R. Douglas and the Cargill Solar Salt Plant for access to the sample locations. This research was funded by grants from the George Mason University Foundation (to C. D. L.), Spanish Ministerio de Educación y Ciencia (BIO2006-06927) and from the Junta de Andalucía (P06CVI-01829) (to A.V.).

\section{References}

Bauer, A. W., Kirby, W. M. M., Sherris, J. C. \& Turck, M. (1966). Antibiotic susceptibility testing by a standardized single disc method. Am J Clin Pathol 45, 493-496.

Benlloch, S., López-López, A., Casamayor, E. O., Øvreås, L., Goddard, V., Daae, F. L., Smerdon, G., Massana, R., Joint, I. \& other authors (2002). Prokaryotic genetic diversity throughout the salinity gradient of a coastal solar saltern. Environ Microbiol 4, 349-360.

Brown, E. J. \& Braddock, J. F. (1990). Sheen screen, a miniaturized most-probable-number method for enumeration of oil-degrading microorganisms. Appl Environ Microbiol 56, 3895-3896.

Castillo, A. M., Gutiérrez, M. C., Kamekura, M., Xue, Y., Ma, Y., Cowan, D. A., Jones, B. E., Grant, W. D. \& Ventosa, A. (2006). Halorubrum orientale sp. nov., a halophilic archaeon isolated from Lake Ejinor, Inner Mongolia, China. Int J Syst Evol Microbiol 56, 2559-2563.

Castillo, A. M., Gutiérrez, M. C., Kamekura, M., Xue, Y., Ma, Y., Cowan, D. A., Jones, B. E., Grant, W. D. \& Ventosa, A. (2007). Halorubrum ejinorense sp. nov., isolated from Lake Ejinor, Inner Mongolia, China. Int J Syst Evol Microbiol 57, 2538-2542.

Cui, H.-L., Tohty, D., Zhou, P.-J. \& Liu, S.-J. (2006). Halorubrum lipolyticum sp. nov. and Halorubrum aidingense sp. nov., isolated from two salt lakes in Xin-Jiang, China. Int J Syst Evol Microbiol 56, 16311634.
Cui, H.-L., Lin, Z.-Y., Dong, Y., Zhou, P.-J. \& Liu, S.-J. (2007). Halorubrum litoreum sp. nov., an extremely halophilic archaeon from a solar saltern. Int J Syst Evol Microbiol 57, 2204-2206.

Fan, H., Xue, Y., Ma, Y., Ventosa, A. \& Grant, W. D. (2004). Halorubrum tibetense sp. nov., a novel haloalkaliphilic archaeon from Lake Zabuye in Tibet, China. Int J Syst Evol Microbiol 54, 1213-1216.

Feng, J., Zhou, P.-J. \& Liu, S.-J. (2004). Halorubrum xinjiangense sp. nov., a novel halophile isolated from saline lakes in China. Int J Syst Evol Microbiol 54, 1789-1791.

Feng, J., Zhou, P., Zhou, Y.-G., Liu, S.-J. \& Warren-Rhodes, K. (2005). Halorubrum alkaliphilum sp. nov., a novel haloalkaliphile isolated from a soda lake in Xinjiang, China. Int J Syst Evol Microbiol 55, 149-152.

Franzmann, P. D., Stackebrandt, E., Sanderson, K., Volkman, J. K., Cameron, D. E., Stevenson, P. L., McMeekin, T. A. \& Burton, H. R. (1988). Halobacterium lacusprofundi sp. nov., a halophilic bacterium isolated from Deep Lake, Antarctica. Syst Appl Microbiol 11, 20-27.

Grant, W. D. \& Ross, H. N. M. (1986). The ecology and taxonomy of halobacteria. FEMS Microbiol Rev 39, 9-15.

Grant, W. D., Kamekura, M., McGenity, T. J. \& Ventosa, A. (2001). The order Halobacteriales. In Bergey's Manual of Systematic Bacteriology, 2nd edn, vol. 1, pp. 294-334. Edited by D. R. Boone, R. W. Castenholz \& G. M. Garrity. New York: Springer.

Johnson, J. L. (1994). Similarity analysis of DNAs. In Methods for General and Molecular Bacteriology, pp. 655-681. Edited by P. Gerhardt, R. G. E. Murray, W. A. Wood \& N. R. Krieg. Washington, DC: American Society for Microbiology.

Kamekura, M. (1998). Diversity of extremely halophilic bacteria. Extremophiles 2, 289-295.

Kamekura, M. \& Dyall-Smith, M. L. (1995). Taxonomy of the family Halobacteriaceae and the description of two new genera Halorubrobacterium and Natrialba. J Gen Appl Microbiol 41, 333-350.

Kamekura, M., Dyall-Smith, M. L., Upasani, V., Ventosa, A. \& Kates, M. (1997). Diversity of alkaliphilic halobacteria: proposals for transfer of Natronobacterium vacuolatum, Natronobacterium magadii, and Natronobacterium pharaonis to Halorubrum, Natrialba, and Natronomonas gen. nov., respectively, as Halorubrum vacuolatum comb. nov., Natrialba magadii comb. nov., and Natronomonas pharaonis comb. nov., respectively. Int J Syst Bacteriol 47, 853-857.

Kharroub, K., Quesada, T., Ferrer, R., Fuentes, S., Aguilera, M., Boulahrouf, A., Ramos-Cormenzana, A. \& Monteoliva-Sánchez, M. (2006). Halorubrum ezzemoulense sp. nov., a halophilic archaeon isolated from Ezzemoul sabkha, Algeria. Int J Syst Evol Microbiol 56, 1583-1588.

Litchfield, C. D. \& Oren, A. (2001). Polar lipids and pigments as biomarkers for the study of the microbial community structure of solar salterns. Hydrobiologia 466, 81-89.

Litchfield, C. D., Sikaroodi, M. \& Gillivet, P. (2005). The microbial diversity of a solar saltern on San Francisco Bay. In Adaptation to Life at High Salt Concentrations in Archaea, Bacteria, and Eukarya, pp. 5969. Edited by N. Gunde-Cimerman, A. Oren \& A. Plemenitas. Dordrecht, The Netherlands: Springer.

Lizama, C., Monteoliva-Sánchez, M., Suárez-Garciá, A., RosellóMora, R., Aguilera, M., Campos, V. \& Ramos-Cormenzana, A. (2002). Halorubrum tebenquichense sp. nov., a novel halophilic archaeon isolated from the Atacama Saltern, Chile. Int J Syst Evol Microbiol 52, 149-155.

Ludwig, W., Strunk, O., Klugbauer, S., Klugbauer, N., Weizenegger, M., Neumaier, J., Bachleitner, M. \& Schleifer, K.-H. (1998). Bacterial phylogeny based on comparative sequence analysis. Electrophoresis 19, 554-568. 
Ludwig, W., Strunk, O., Westram, R., Richter, L., Meier, H., Yadhukumar, Buchner, A., Lai, T., Steppi, S. \& other authors (2004). ARB: a software environment for sequence data. Nucleic Acids Res 32, 1363-1371.

Marmur, J. (1961). A procedure for the isolation of deoxyribonucleic acid from microorganisms. J Mol Biol 3, 208-218.

Marmur, J. \& Doty, P. (1962). Determination of the base composition of deoxyribonucleic acid from its thermal denaturation temperature. $J$ Mol Biol 5, 109-118.

McGenity, T. \& Grant, W. D. (1995). Transfer of Halobacterium saccharovorum, Halobacterium sodomense, Halobacterium trapanicum NRC 34021 and Halobacterium lacusprofundi to the genus Halorubrum gen. nov., as Halorubrum saccharovorum comb. nov., Halorubrum sodomense comb. nov., Halorubrum trapanicum comb. nov., and Halorubrum lacusprofundi comb. nov. Syst Appl Microbiol 18, 237-243.

McGenity, T. J. \& Grant, W. D. (2001). Genus VII. Halorubrum. In Bergey's Manual of Systematic Bacteriology, 2nd edn, vol. 1, pp. 320324. Edited by D. R. Boone, R. W. Castenholz \& G. M. Garrity. New York: Springer.

Mormile, M. R., Romine, M. F., Garcia, M. T., Ventosa, A., Bailey, T. J. \& Peyton, B. M. (1999). Halomonas campisalis sp. nov., a denitrifying, moderately haloalkaliphilic bacterium. Syst Appl Microbiol 22, 551558.

Mwatha, W. E. \& Grant, W. D. (1993). Natronobacterium vacuolata sp. nov., a haloalkaliphilic archaeon isolated from Lake Magadi, Kenya. Int J Syst Bacteriol 43, 401-404.

Ochsenreiter, T., Pfeifer, F. \& Schleper, C. (2002). Diversity of Archaea in hypersaline environments characterized by molecularphylogenetic and cultivation studies. Extremophiles 6, 267-274.

Oren, A. (1983). Halobacterium sodomense sp. nov., a Dead Sea halobacterium with an extremely high magnesium requirement. Int $J$ Syst Bacteriol 33, 381-386.

Oren, A. (2002a). Diversity of halophilic microorganisms: environments, phylogeny, physiology, and applications. J Ind Microbiol Biotechnol 28, 56-63.

Oren, A. (2002b). Molecular ecology of extremely halophilic Archaea and Bacteria. FEMS Microbiol Ecol 39, 1-7.
Oren, A. \& Ventosa, A. (1996). A proposal for the transfer of Halorubrobacterium distributum and Halorubrobacterium coriense to the genus Halorubrum as Halorubrum distributum comb. nov. and Halorubrum coriense comb. nov., respectively. Int J Syst Bacteriol 46, 1180.

Oren, A., Ventosa, A. \& Grant, W. D. (1997). Proposed minimal standards for description of new taxa in the order Halobacteriales. Int J Syst Bacteriol 47, 233-238.

Owen, R. J. \& Hill, L. R. (1979). The estimation of base compositions, base pairing and genome sizes of bacterial deoxyribonucleic acids. In Identification Methods for Microbiologists (Society for Applied Bacteriology Technical Series no. 14), 2nd edn, pp. 277-296. Edited by F. A. Skinner \& D. W. Lovelock. London: Academic Press.

Soto, C. Y., Cama, M., Gibert, I. \& Luquin, M. (2000). Application of an easy and reliable method for sulfolipid-I detection in the study of its distribution in Mycobacterium tuberculosis strains. FEMS Microbiol Lett 187, 103-107.

Stackebrandt, E. \& Goebel, B. M. (1994). Taxonomic note: a place for DNA-DNA reassociation and 16S rRNA sequence analysis in the present species definition in bacteriology. Int J Syst Bacteriol 44, 846849.

Tindall, B. J. (1990). Lipid composition of Halobacterium lacusprofundi. FEMS Microbiol Lett 66, 199-202.

Tomlinson, G. A. \& Hochstein, L. I. (1976). Halobacterium saccharovorum sp. nov., a carbohydrate-metabolizing, extremely halophilic bacterium. Can J Microbiol 22, 587-591.

Ventosa, A., Gutiérrez, M. C., Kamekura, M. \& Dyall-Smith, M. L. (1999). Proposal to transfer Halococcus turkmenicus, Halobacterium trapanicum JCM 9743 and strain GSL-11 to Haloterrigena turkmenica gen. nov., comb. nov. Int J Syst Bacteriol 49, 131-136.

Ventosa, A., Gutiérrez, M. C., Kamekura, M., Zvyagintseva, I. S. \& Oren, A. (2004). Taxonomic study of Halorubrum distributum and proposal of Halorubrum terrestre sp. nov. Int J Syst Evol Microbiol 54, 389-392.

Xu, X.-W., Wu, Y.-H., Zhang, H.-b. \& Wu, M. (2007). Halorubrum arcis sp. nov., an extremely halophilic archaeon isolated from a saline lake on the Qinghai-Tibet Plateau, China. Int J Syst Evol Microbiol 57, 1069-1072. 